\title{
Microbiological biostimulant promotes rooting of olive cuttings
}

\author{
Giovana Ritter ${ }^{1}$, Fabíola Villa ${ }^{1}$, Daniel Fernandes da Silva ${ }^{1}$, Odair Alberton ${ }^{2}$, \\ Fernanda Jaqueline Menegusso ${ }^{1}$, Tatiane Eberling ${ }^{1}$, Joyce Dória ${ }^{3 *}$ \\ (1. Western Paraná State University (Unioeste), Campus Marechal Cândido Rondon. Marechal Cândido Rondon, PR, 85960-000, Brazil; \\ 2. Paranaense University (UNIPAR), Umuarama, PR, 87502-210, Brazil; \\ 3. Federal University of Lavras, Lavras, MG, 37200-000, Brazil)
}

\begin{abstract}
The most widely used method of olive propagation is cutting, although for some cultivars the technique is still limited. The objective of this work was to evaluate the use of plant growth promoter bacteria and arbuscular mycorrhizal fungi in the rooting of olive cuttings. Two experiments were conducted from October 2017 to January 2018 with cuttings from 4 olive cultivars (Ascolano 315, Koroneiki, Maria da Fé and Picual) from four-year-old plants. The first experiment consisted of 4 olive cultivars and 3 mycorrhizal species plus the control and the second experiment of 3 concentrations of commercial inoculant $\left(\right.$ Nitro $\left.1000^{\circledR}\right)$, containing Azospirillum brasilense plus control. The cuttings were treated with $3000 \mathrm{mg} / \mathrm{L}$ of indolebutyric acid (IBA). The experimental design used in the two experiments was randomized blocks, in a $4 \times 4$ factorial scheme, containing 25 stakes per replicate and 3 replicates. The cuttings were kept under weaver conditions and within a low rooting tunnel. After $75 \mathrm{~d}$, the percentage of rooted cuttings, callus and sprouts, length of the largest root, number and length of shoots were evaluated. The use of FMA in Maria da Fé and Picual has a positive response to cutting rooting and the fungi benefit the quality of the seedlings by the higher number of shoots and larger root length. The relation of Azospirillum brasilense cultivar is specific, being that, the cultivar Picual does not respond to inoculation of the bacterium having less viability in the propagation by cutting. Maria da Fé and Koroneiki have the best percentages of rooting with the use of 75.00 and $52.00 \mathrm{~mL} / \mathrm{L}$ of inoculant, respectively.
\end{abstract}

Keywords: Azospirillum brasilense, arbuscular mycorrhizal fungi, propagation, Olea europaea L., microorganism DOI: $10.25165 /$ j.ijabe.20211406.5880

Citation: Ritter G, Villa F, da Silva D F, Alberton O, Menegusso F J, Eberling T, et al. Microbiological biostimulant promotes rooting of olive cuttings. Int J Agric \& Biol Eng, 2021; 14(6): 207-212.

\section{Introduction}

Seedling with high quality input, directly on the formation of the orchard. Regarding propagation, the olive fruit has seed with viability, but the sexual reproduction is not desired for commercial orchards because plants present different characteristics from their mother plants, heterogeneity and a long juvenile period ${ }^{[1]}$ and in this way, the vegetative or asexual propagation is the most viable technique for the seedlings formation, maintaining the main characteristics and anticipating the production ${ }^{[2,3]}$.

For olive tree, stem cutting is the most widely used propagation form and this method is the root regeneration from a branch segment, but there is still difficulty in the efficiency of this method for the species due to the different behaviour between the cultivars $^{[4]}$.

The main factors involved in rooting cuttings are hormonal

\section{Received date: 2020-04-28 Accepted date: 2021-06-29}

Biographies: Giovana Ritter, $\mathrm{PhD}$ candidate, research interest: fruit science, Email: rittergiovana@gmail.com; Fabíola Villa, PhD, Professor, research inetrest: fruit science, Fruit growing, Floriculture, fvilla2003@hotmail.com; Daniel Fernandes da Silva, PhD research interest: fruit science, Fruit growing, applied botany, Email: daniel_eafi@yahoo.com.br; Odair Alberton, PhD, research interest: soil microbiology and biochemistry, Email: odair@prof.unipar.br; Fernanda Jaqueline Menegusso, $\mathrm{PhD}$, research interest: floriculture and landscape, Email: fjmenegusso@gmail.com; Tatiane Eberling, PhD candidate, research interest: floriculture, Email: tatianeeberling@hotmail.com.

*Corresponding Author: Joyce Dória, PhD, Professor, research interest: Plant Growth Promoting Bacteria, Federal University of Lavras, 37200-000, Lavras, MG, Brazil. Email: joyce.doria@ufla.br. balance, the genetic constitution of parent plant as their potential and genetic viability inside the species, maturation/youthfulness of propagating material, period of the year for collection, and the abiotic factors as temperature, light and humidity, use of growth regulator and substrate quality ${ }^{[2]}$. Many researches on olive cuttings ${ }^{[5-7]}$ mentioned the low rooting percentage of cuttings from various cultivars, highlighted the need for the appliance of exogenous auxin and more studies to induce the cuttings rhizogenesis and maximize the process.

The arbuscular mycorrhizal fungi (AMF) are a microorganisms group able to realize beneficial mutualistic symbioses association with plants wherewith fungi issues an interactive structure into vegetal cortex called arbuscule ${ }^{[8]}$. The olive trees show in their roots an intense AMF colonization, mainly the Gigasporaceae, Acaulosporaceae and Glomaceae families proving the fungus-plant compatibility ${ }^{[9]}$.

Positive results were observed by Bompadre et al. ${ }^{[10]}$, affirming that inoculating AMF in seedlings production phase is beneficial for their development, facilitating transplanting in the field. In addition to the factors mentioned above, there is a guarantee of these fungi survival and dispersion in successive phases, with occurrences by the formation of spores in the extra radicular hyphae ${ }^{[8]}$.

Another group of microorganism also used in fruticulture is the plant growth promoting bacteria (PGPB). Studies show that PGPB can stimulate plant growth through their ability to produce plant hormones such as auxin, gibberellins, cytokines, ethylene and abscisic acid ${ }^{[11]}$, being indoleacetic acid (IAA) the most produced by these bacteria ${ }^{[12]}$. Among all species of bacteria, those who 
belong to Azospirillum genre are the most well-known and studied IAA producers and their effects are related to the growth of roots and morphology $y^{[13]}$. For not being an obligatory host, this genus can colonize surface areas or even be installed in other plant organs as phylloplane and internal tissues ${ }^{[14]}$.

Both microorganisms can be used as biostimulants in plants. The diversity of biostimulants is very large and in addition to their use in plants, some can be applied in other agricultural sectors ${ }^{[15,16]}$.

Given the above, the objective of this work was to study the rooting of olive cuttings using together with the IBA synthetic hormone, arbuscular mycorrhizal fungi and plant growth promoter bacteria.

\section{Materials and methods}

Two experiments were developed from October 2017 to January 2018, conducted at plant nursery of the Horticulture Experimental Station and Protected Cultivation "Professor Mário César Lopes" from the Western Paraná State University (Unioeste), Campus Marechal Cândido Rondon (PR). The plant nursery is located at geographical coordinates of latitude $24^{\circ} 32^{\prime} 22^{\prime \prime} \mathrm{S}$, longitude $54^{\circ} 03^{\prime} 24^{\prime \prime} \mathrm{W}$ and $420 \mathrm{~m}$ height.

The region climate according to Köppen classification is the type Cfa humid subtropical ${ }^{[17]}$, with annual average precipitation between 1600 and $1800 \mathrm{~mm}$ and relative humidity between $70 \%-75 \%{ }^{[18]}$. The annual average temperature is in the range of $22^{\circ} \mathrm{C}-23^{\circ} \mathrm{C}$. The experiment conduction occurred under shading screens conditions with $50 \%$ retention of solar radiation. The cutting rooting occurred in masonry bed filled with sterilized and washed sand of average size (Figure 1a). Over the bed, a rooting tunnel was built $(5.00 \mathrm{~m}$ in length, $0.80 \mathrm{~m}$ in width and $0.55 \mathrm{~m}$ in height), using wood and covered with $150 \mu \mathrm{m}$ transparent plastic. Inside the tunnel there was a micro sprinkler irrigation system, with activation from 7:00 a.m. to 6:00 p.m., every $30 \mathrm{~min}$ for $3 \mathrm{~min}$, to keep the high air and substrate humidity.
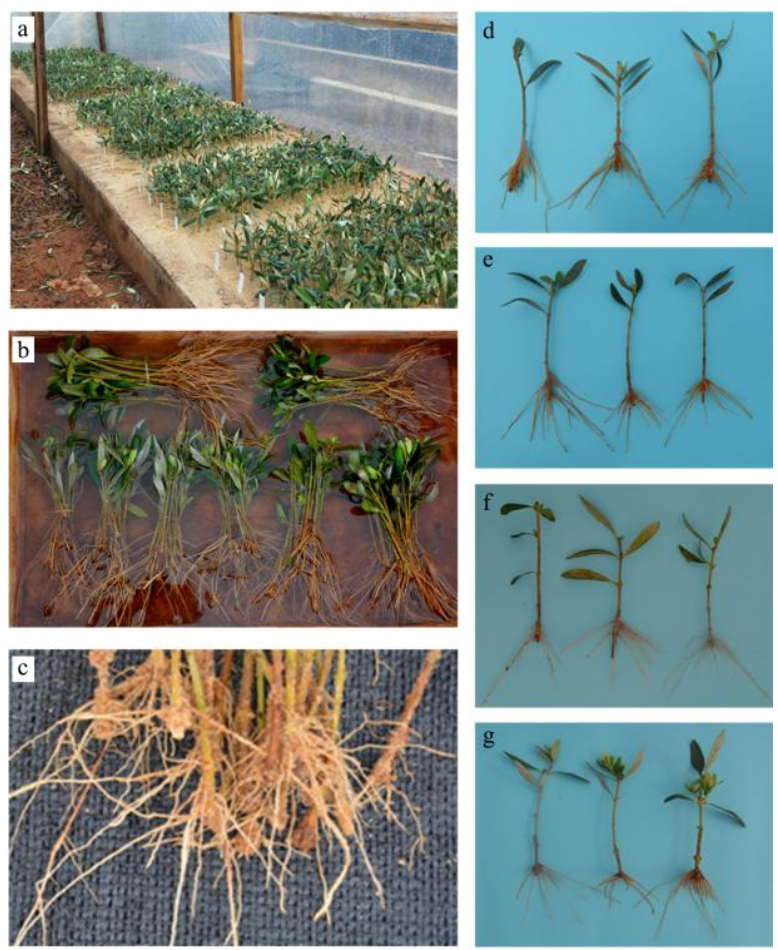

Figure 1 Cuttings in the rooting bed (a); After $75 \mathrm{~d}$ (b); Root system (c); Olive cuttings from Koroneiki and Ascolano 315 control treatment (d-e), Maria da Fé inoculated with Glomus etunicatum (f) and Picual inoculated with Glomus clarum (g)
For the experiments, cuttings from four olive cultivars were used, Koroneiki, Ascolano (MGS ASC315), Maria da Fé (MGS Mariense) and Picual, withdrawals from branches collected from four-year-old parent plants, cultivated at Unioeste's Experimental Farm. The gathering occurred in the morning and cuttings from middle third position of straight branches without budding buds were used.

The branches were collected in October 2017 and immediately transported to the nursery to prepare the cuttings. These were prepared $12 \mathrm{~cm}$ long and $4 \mathrm{~mm}$ in diameter, keeping two pairs of leaves at the top and straight cut at the base ${ }^{[19]}$. Then all cuttings in both experiments were treated with $3000 \mathrm{mg} / \mathrm{L}$ indolebutyric acid (IBA), being the base immersed in the solution for $15 \mathrm{~s}$, and then taken to the sand bed and arranged in spacing of $5 \mathrm{~cm} \times 3 \mathrm{~cm}$, with $5 \mathrm{~cm}$ of its buried length (Figure 1a).

To monitor the environmental conditions inside the tunnel, a datalogger ${ }^{\circledR}$ was installed inside a meteorological shelter, making hourly measurements of the temperature and relative humidity of the air throughout the experimental period. The average air temperature and relative humidity were $22^{\circ} \mathrm{C}$ and $78.7 \%$, respectively (Figure 2).

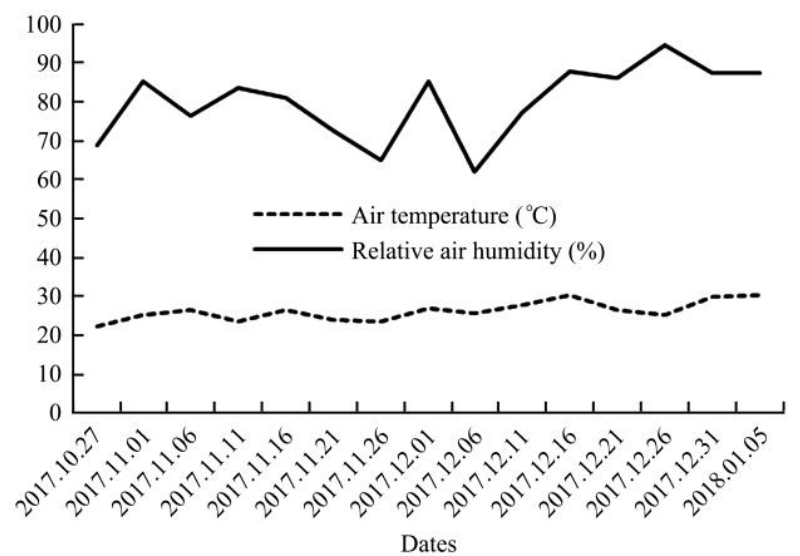

Figure 2 Air temperature and relative air humidity measured during the experiment

In experiment I, before disposing the cuttings, three spaces were separated $(0.75 \mathrm{~m} \times 0.80 \mathrm{~m})$ in the site, keeping a small distance between them to avoid contact between the microorganisms (arbuscular mycorrhizal fungi).

Three species of arbuscular mycorrhizal fungi (AMF) were used: Gigaspora margarita, Glomus clarum and Glomus etunicatum, from the Active Germplasm Bank of the University of Paraná (UNIPAR), Campus of Umuarama, PR. For inoculation of AMF, $2 \mathrm{~kg}$ of a mixture of soil, sand and roots, containing the spores of each AMF and incorporated at a depth of $5 \mathrm{~cm}$, was added to the bed sand, mixing with the sand present in the bed.

To calculate the number of spores, an estimate was made for each AMF from the density in $50 \mathrm{~g}$ of soil (DE 50). Given this calculation, $2 \mathrm{~kg}$ of the mixture with Gigaspora margarita (DE $50=71$ ) deposited around 2840 spores. For Glomus clarum (DE $50=64$ ) around 2560 spores were added and for G. etunicatum (DE $50=118$ ) around 4720 spores. The design used in experiment I was the randomized block in a $4 \times 4$ factorial scheme ( $3 \mathrm{AMF}$ species + control $\times 4$ olive cultivars), containing 3 replications of 25 cuttings each, totaling 1200 cuttings.

In experiment II, before the cutting preparation, four spaces were divided, where the concentrations of A. brasilense were inoculated, with distance between treatments, in order to avoid the contact between the microorganisms present. To prepare the 
solution with $A$. brasilense, the commercial product Nitro1000 ${ }^{\circledR}$ (containing strains AbV5, AbV6 and 200 million cells/mL) was used. The treatments used were $0,50,100$ and $150 \mathrm{~mL}$, adding water until reaching the volume of $2 \mathrm{~L}$, giving the concentrations of $0,25 \mathrm{~mL} / \mathrm{L}, 50 \mathrm{~mL} / \mathrm{L}$ and $75 \mathrm{~mL} / \mathrm{L}$ of Nitro $1000^{\circledR}$, respectively. The solutions were applied evenly to the piles arranged in the sand bed with the aid of watering can.

Experiment II was a randomized block design in a $4 \times 4$ factorial scheme ( 3 concentrations of the solution containing Azospirillum brasilense + control $\times 4$ olive cultivars), containing 3 replications of 25 cuttings each, totaling 1200 cuttings.

After $75 \mathrm{~d}$, the percentage of rooted cuttings was evaluated, calli and cuttings $(\%)$, length of the largest root $(\mathrm{cm})$, number of shoots and length of shoots $(\mathrm{cm})$. To measure the lengths a digital caliper was used.

The data were tabulated and the Shapiro-wilk test of normality was applied, being transformed to $(\mathrm{Y}+1.0)^{0.5}$ when necessary, subsequently submitted to analysis of variance and the means compared by the Tukey test at $5 \%$ probability of error for the first experiment. For the averages of experiment II, the Tukey test for qualitative data and regression analysis for quantitative data were used. For the analysis of the results, the statistical program Sisvar was used $^{[18]}$

\section{Results}

\subsection{Experiment I}

Through the analysis of variance a significant interaction was verified between AMF and olive cultivars just for rooted cuttings percentage (Figures 1b-1c, Table 1). For Koroneiki and Ascolano (Figures 1d-1e) the rooting percentage was higher than the control treatment and Picual showed the lowest rooting percentage in this treatment.

Table 1 Rooting percentage of cuttings in relation to cultivars and AMF

\begin{tabular}{lcccc}
\multirow{2}{*}{ AMF } & \multicolumn{5}{c}{ Olive cultivars } \\
\cline { 2 - 5 } & Koroneiki & Ascolano 315 & Maria da Fé & Picual \\
\hline Control treatment & $46.29 \mathrm{aA} *$ & $52.00 \mathrm{aA}$ & $36.33 \mathrm{bAB}$ & $22.67 \mathrm{bB}$ \\
Gigaspora margarita & $23.10 \mathrm{aB}$ & $25.73 \mathrm{bAB}$ & $48.00 \mathrm{abA}$ & $38.30 \mathrm{abAB}$ \\
Glomus clarum & $31.10 \mathrm{aB}$ & $52.00 \mathrm{aAB}$ & $69.33 \mathrm{aA}$ & $54.67 \mathrm{aAB}$ \\
Glomus etunicatum & $35.40 \mathrm{aB}$ & $49.33 \mathrm{abAB}$ & $72.60 \mathrm{aA}$ & $36.00 \mathrm{abB}$ \\
\hline CV/\% & \multicolumn{4}{c}{13.87} \\
\hline
\end{tabular}

Note: * Lowercase letters differ statistically from each other in the column and uppercase in the row by Tukey test at $5 \%$ error probability; CV: Coefficient of variation.

For Maria da Fé and Picual unlike the other two evaluated there was a rooting increase with AMF inoculation proved by statistical difference, highlighting the Maria da Fé cultivar where the two higher percentages can be verified on cutting treated with Glomus etunicatum (Figure 1f) and Glomus clarum (Figure 1g) (72.60\% and $69.33 \%$, respectively). Also, Gigaspora margarita fungi showed higher results in relation to the control treatment which demonstrates the beneficial effect of using these microorganisms for these cultivars. For Koroneiki there was no difference between treatments, and for Ascolano 315 the inoculation of Glomus genre fungi did not differ from the control treatment but cuttings treated with Gigaspora margarita presented the lowest rhizogenic potential.

For calloused and sprouted cuttings percentage and root number a significance was verified only for cultivar (Table 2).
Taking into account the calloused cuttings' percentage the Ascolano 315 showed the lowest value which can be related to its high rooting percentage (52\%). The Koroneiki and Maria da Fé which presented the highest values for callous cuttings did not show higher rooting percentages.

Table 2 Calloused cuttings percentage (CC), sprouted cuttings (SC), root number (RN) and largest root length (LRL) in relation to olive cultivars

\begin{tabular}{lcccc}
\hline Olive cultivars & CC/\% & SC/\% & RN & LRL/cm \\
\hline Koroneiki & $19.58 \mathrm{a}^{*}$ & $24.69 \mathrm{ab}$ & $7.95 \mathrm{c}$ & $9.18 \mathrm{a}$ \\
Ascolano 315 & $1.33 \mathrm{c}$ & $30.40 \mathrm{ab}$ & $16.47 \mathrm{a}$ & $10.32 \mathrm{a}$ \\
Maria da Fé & $10.97 \mathrm{ab}$ & $39.32 \mathrm{a}$ & $10.27 \mathrm{bc}$ & $6.86 \mathrm{~b}$ \\
Picual & $6.96 \mathrm{~b}$ & $21.29 \mathrm{~b}$ & $13.52 \mathrm{ab}$ & $5.79 \mathrm{~b}$ \\
$\mathrm{CV}^{1} \%$ & 24.01 & 26.28 & 13.84 & 18.96 \\
\hline
\end{tabular}

Note: * Lowercase letters differ statistically from each other in the column by Tukey test at $5 \%$ error probability; ${ }^{1}$ Coefficient of variation.

The budding of cuttings during rooting is directly related to the formation of the roots because in both processes there is a need for carbohydrate consumption present in the cuttings and cuttings with greater reserves tend to sprout and root easier but the reserves are not always sufficient for rooting, just for sprout as occurred with Maria da Fé and Koroneiki cultivars, which presented high percentage of sprouted cuttings but were not superior in rooting (Table 2)

The largest root length showed significance both for the cultivar factor and for the inoculation with fungi being that in the Koroneiki and Ascolano cultivars the largest root length was statistically higher than the Maria da Fé and Picual, possibly attributed to the genotype (Table 2).

When submitted to fungi inoculation, the largest root length was higher in all treatments, if compared to the control treatment, proving the benefit of AMF on olive cuttings rooting (Table 3). Table 3 shows the number of sprouts where the averages were higher when submitted to treatments with mycorrhizal fungi however shoot length was higher when only the IBA plant growth regulator was used.

Table 3 Sprout number (SN), sprout length (SL) and largest root length (LRL) in relation to treatments with arbuscular mycorrhizal fungi (AMF)

\begin{tabular}{lccc}
\hline \multicolumn{1}{c}{ AMF } & SN & SL/cm & LRL/cm \\
\hline Control treatment & $1.27 \mathrm{~b}^{*}$ & $1.57 \mathrm{a}$ & $6.09 \mathrm{~b}$ \\
Gigaspora margarita & $1.65 \mathrm{a}$ & $1.26 \mathrm{~b}$ & $8.82 \mathrm{a}$ \\
Glomus clarum & $1.67 \mathrm{a}$ & $1.32 \mathrm{~b}$ & $9.13 \mathrm{a}$ \\
Glomus etunicatum & $1.70 \mathrm{a}$ & $1.30 \mathrm{~b}$ & $8.12 \mathrm{a}$ \\
$\mathrm{CV}^{1} / \%$ & 10.08 & 10.56 & 18.96
\end{tabular}

Note: * Lowercase letters differ statistically from each other in the column by Tukey test at $5 \%$ error probability.

${ }^{1}$ Coefficient of variation.

\subsection{Experiment II}

Figure $3 \mathrm{a}$ shows the rooting percentage of olive cultivars in relation to the inoculant with Azospirillum brasilense concentrations. The rooting cuttings' percentage for Koroneiki presents a curve with an optimum inoculant concentration peak estimated at $55 \mathrm{~mL} / \mathrm{L}$.

For Maria da Fé the answer was increasing and linear, that is, according to the increase in inoculant concentration, rooting percentage increased as well, being $75 \mathrm{~mL} / \mathrm{L}$ the best concentration. The Ascolano and Picual cultivars do not present rooting variation in the tested concentrations. 

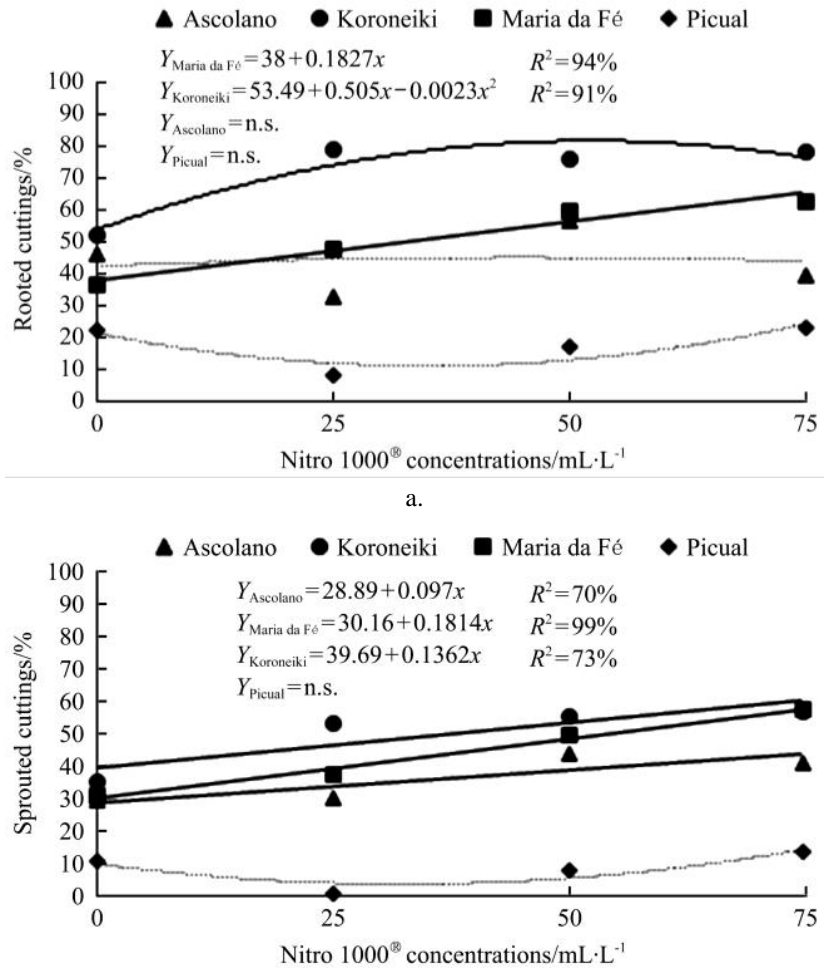

b.

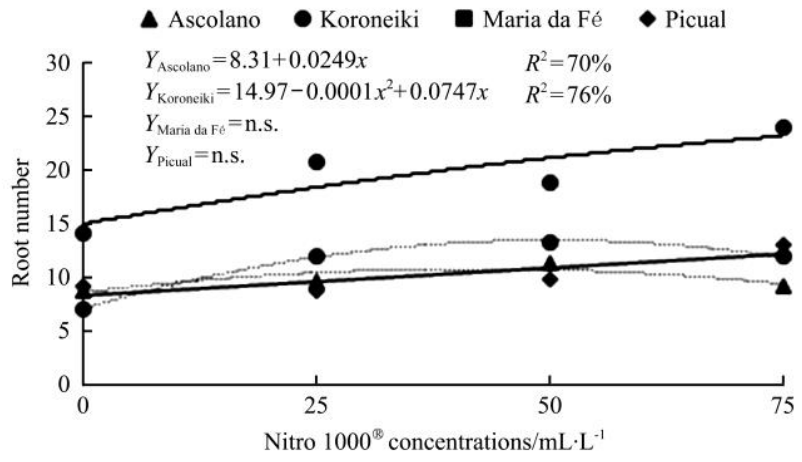

c.

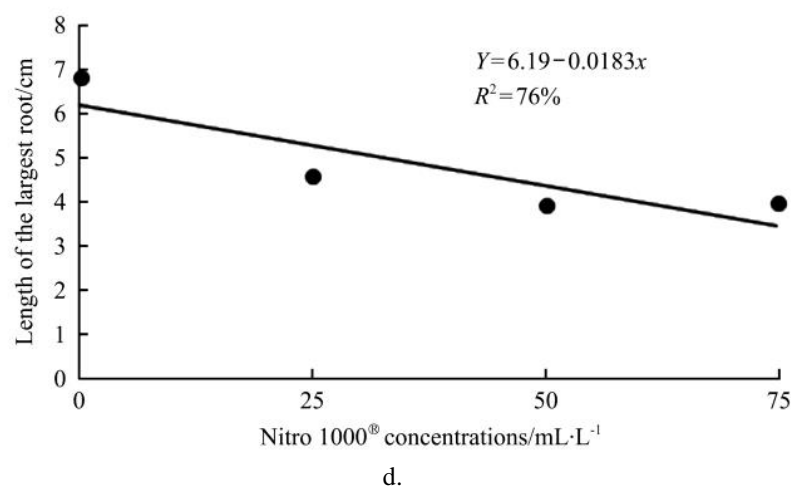

Figure 3 Rooting cuttings percentage (a), sprouted (b), root number (c) and average root length (d) of olive cultivars in relation to Nitro $1000^{\circledR}$ inoculant concentrations

According to the variance analysis for calloused cuttings, sprout length and largest root length parameters, there was a significant effect for cultivar factor (Table 4) while the shoots number did not present significant differences. For Picual, there was a calloused cuttings percentage higher than Ascolano 315, but statistically not different from Maria da Fé and Koroneiki, which did not differ from Ascolano 315.

The Ascolano cuttings presented a peculiar behaviour in which there is a low callus formation on the cuttings and almost all of them presented rooted or dead at the time of evaluation

Table 4 Calloused cuttings (CC), sprouts length (SL) and largest root length (LRL) of olive cultivars in relation to Azospirillum brasilense inoculation

\begin{tabular}{|c|c|c|c|}
\hline Olive cultivars & $\mathrm{CC} / \%$ & $\mathrm{SL} / \mathrm{cm}$ & $\mathrm{LRL} / \mathrm{cm}$ \\
\hline Ascolano 315 & $0.01 \mathrm{a}^{*}$ & $0.59 \mathrm{a}$ & $4.99 \mathrm{a}$ \\
\hline Koroneiki & $10.67 \mathrm{ab}$ & $0.71 \mathrm{a}$ & $5.69 \mathrm{a}$ \\
\hline Maria da Fé & $12.00 \mathrm{ab}$ & $0.68 \mathrm{a}$ & $3.63 \mathrm{~b}$ \\
\hline Picual & $15.17 \mathrm{~b}$ & $0.35 \mathrm{~b}$ & $2.62 \mathrm{~b}$ \\
\hline $\mathrm{CV}^{1} / \%$ & 21.66 & 6.70 & 23.99 \\
\hline
\end{tabular}

Note: $*$ Lowercase letters differ statistically from each other in the column by Tukey test at $5 \%$ error probability;

${ }^{1}$ Coefficient of variation.

In the sprouts length, the cultivar Picual is evidenced to have statistically smaller shoots possibly influenced by their genotype because in another evaluated parameters related to aerial part and also presents non satisfactory results in seedlings formation as from cuttings.

In accordance with these statements, for the olive cuttings rhizogenesis, the shoots appear to be beneficial because the cultivars with higher sprouted cuttings percentage and largest shoot length were also the ones that presented greater rooting (Table 4, Figure 3b).

As the previously described, the cuttings budding did not mean total success in the rooting process because shoots could occur due to nutrient reserves in the cutting. For the cuttings sprouts in relation to inoculant concentration, only Picual did not present significant effect. For the others, there was a positive linear response (Figure $2 \mathrm{~b}$ ).

The inoculant concentration of $75 \mathrm{~mL} / \mathrm{L}$ with $A$. brasilense presented the best sprouting rates which can be related to the microorganisms' production of indol-3-acetic acid (IAA), improving the cutting hormonal balance, providing rooting and sprouting.

The root system quality expressed by root length and number differed between cultivars. For koroneiki and Ascolano 315 which was higher without A. brasilense inoculant (Table 4), the same cultivars that obtained higher root number when treated with $75 \mathrm{~mL} / \mathrm{L}$ of commercial product (Figure $3 \mathrm{c}$ ). In relation to Nitro $1000^{\circledR}$ concentration, a decrease can be observed on largest root length according to the increased concentration used, being the best performance without the product using (Figure $3 \mathrm{~d}$ ).

\section{Discussion}

\subsection{Experiment I}

The rooting can be considered an intrinsic characteristic of the cultivars because similar results were found ${ }^{[5]}$ that assessing the olive cuttings rooting in different substrates, observed lower rooting percentage for Picual cultivar which even at its best potential in sand substrate obtained $17 \%$.

Highlighting the low rooting ability of Picual in relation to other genotypes, Villa found $49 \%$ cuttings rooting of this cultivar in sand substrate, occupying an intermediate position among ten evaluated cultivars ${ }^{[7]}$. Thus, due to the largest olive genotype number described in the literature, it is possible to divide cultivars between easy, medium and difficult rooting, even if this parameter is the result of the interaction between several biotic and abiotic factors and not only the genetic potential ${ }^{[21]}$.

The positive interaction between mycorrhizal and Maria da Fé cultivar in this experiment can be related that these same AMF 
genres are easily found in the rhizosphere of this cultivar adult plants, according to Vieira, being this association a natural occurrence in the environment ${ }^{[22]}$.

The beneficial relation between mycorrhizal and olive tree rhizosphere is widely reported in the literature, for example, the report of Kachkouf on the association of olive roots and AMF mainly Glomus and Gigaspora genres in different places in Morocco $^{[9]}$, or the findings of Chatzistathis, that describe the presence of the same genres associated with the roots of Greek olive cultivars ${ }^{[23]}$, and Ferreira, on the verification that the presence of these fungi provides greater aerial part and roots dry biomass of olive trees seedlings developed in nursery ${ }^{[24]}$.

According to Fachinello, the callus formation may or not be a process associated to the rooting because its formation is a regeneration cutting in response to the xylem and phloem vessels cut $^{[2]}$. This undifferentiated cell mass denominated callus can evolve to differentiate into adventitious roots or act as an injury healer preventing dehydration in the injured area.

Analyzing the callus formation in olive cutting, the callus formation in Picual cultivar was also lower compared to the other cultivars in the studies of Villa ${ }^{[7]}$. However, for Koroneiki, Penso found $60 \%$ of calloused, a result three times bigger than this study, emphasizing that the formation of roots is a factor associated with the rhizogenic potential of each genotype and not conditioned to the callus pre-existence ${ }^{[6]}$.

Stakes with higher reserves tend to sprout and root more easily, but some cultivars sprouts due to cuttings endogenous reserve being not enough for the roots' eminence will decrease the cuttings rhizogenic potential ${ }^{[21]}$

About the root number, many authors also found differences in the variable $e^{[7,25]}$. These differences can occur due to many extrinsic and intrinsic factors as used substrate, mother plant phenological stage, collect period and cultivar which directly interfere in the reserves flow and mobilization affecting root production $^{[26]}$.

Highlighting the genotype influence on the number of roots formed, Hechmi found variation between the three studied cultivars being average of 1.8 for Picual and 2.6 for Koroneiki ${ }^{[5]}$, both results lower than the results in the present study that despite having a higher number of roots per cutting, Koroneiki had the lowest performance between cultivar evaluated.

For root length, when inoculated with AMF, the high value is due to their greater potential for promoting plant development, mainly in soils with low fertility ${ }^{[27]}$, in this case, the sand, inert substrate used in the experiment.

When cuttings develop sprouts, the sugar and nutrients are translocated being directed to shoots according to source/drain relation and a higher shoot number promote nutrient allocation decreasing their growth $^{[28]}$. The AMF inoculation can act on the cutting shoots formation and development because one of these microorganisms benefits is the increase in the nutrients and water absorption transferring them to the plant tissue with which they are directly in contact ${ }^{[29]}$, and the cutting receive a nutrient subsidy even if still does not have roots promoting shoots and their stretching.

\subsection{Experiment II}

Different behaviors can be observed in relation to inoculant concentration on studied genotypes. Corroborating the present study results, Silva shows positive rooting results for olive cuttings of Arbequina and Grappolo 541 cultivars inoculated with $A$. brasilense $^{[30]}$. However, for Ascolano 315, there was no increase in rooting percentage, which can indicate a low interaction between this genotype and this diazotrophic bacterium, so this interaction between microorganisms and cultivars can be selective and depends on the used cultivar.

A similar result about callus formation was observed by Oliveira, when Ascolano 315 cutting was treated with IBA growth regulator resulting in much lower calloused values when compared to the rooting ${ }^{[31]}$.

For cuttings sprouting during rooting, many factors are involved as available reserve and even the roots formation ${ }^{[32]}$. The sprout in cuttings during rooting can be beneficial because the phytohormone synthesis as auxins actives in this process occurs in yolks and young plants, besides the synthesis of phenol compounds which, in interaction with these auxins, can induce root formation ${ }^{[33]}$. These sprouts can also increase the photosynthetic area of the plant in formation. On the other hand, shoots formed before roots act as drains of carbohydrates and nitrogen compounds which may lead to the exhaustion of these reserves and consequent cutting death $^{[34]}$.

The low sprouted cuttings percentage for Picual cultivar can be a genotype inherent characteristic since it showed reduced length shoots in relation to other studied cultivars. This percentage variation of sprouted cuttings between different genotypes of the same species is related to other temperate zone fruitful trees as an example of peach tree studied by $\operatorname{Rosa}^{[24]}$ and blackberry plants $^{[35]}$.

The inoculant concentration of $75 \mathrm{~mL} / \mathrm{L}$ with Azospirillum brasilense presented the best sprouting rates which can be related to the fact that microorganisms produce indol-3-acetic acid (IAA) improving the hormonal cutting balance and providing rooting and sprouting ${ }^{[36]}$. This interaction may or may not occur in relation to olive cultivar confirmed by Silva et al. ${ }^{[30]}$, who verified increase in sprout percentage in Grapollo cultivar cuttings with A. brasilense inoculation, decreasing this parameter in Ascolano cultivar in the same treatment and also Arbequina cultivar, indifferent with the presence of the microorganism.

The differentiation in the number of adventitious roots relates to the relationship between the plant genotype and the inoculated microorganism according to reference ${ }^{[37]}$, the cultivars respond differently to bacterium colonization being this related to the chemotaxis where each cultivar present a chemical composition different from their root exudates attracting or not the bacteria to these carbon sources which may have influenced root length in these cultivars making them stretching ${ }^{[37]}$. On the other hand, the high population of $A$. brasilense colonizing the root system increase the vegetal regulator availability mainly auxin which compromises the roots elongation causing inhibitory effects ${ }^{[14]}$.

\section{Conclusions}

The use of microorganisms has been shown to be efficient in the seedling formation process and due to high diversity olive cultivar and mycorrhizal fungi species and plant growth promoting bacteria. Further studies of this association are necessary so that their use becomes a widespread practice in agriculture.

\section{Acknowledgements}

The authors acknowledge the financial support of Coordination for the Improvement of higher Education Personnel (CAPES). 


\section{[References]}

[1] Souza R A V, Braga F T, Vieira Neto J, Mendonça E A F, Azevedo P H. Viability and germination of olive embryos subjected to different conditions of fruit storage. Pesq. Agrop. Bras, 2011; 46(3): 309-314.

[2] Fachinello J C, Hoffmann A, Nachtigal J C. Fruit plants propagation. Brasília, 2011; 221p.

[3] Smarsi R C, Chagas E A, Reis L L, Oliveira G F, Mendonça V. Concentrations of indolebutyric acid and kinds of substrates in the vegetative propagation of litchi. Rev. Bras. Fruit, 2008; 30(1): 7-11.

[4] Mohamed Y I. Evaluation the effect of rooting media and hormonal concentrations (IBA) in three olive cultivars growing in SiwaOesis-Egypt. International J. Agric Sci, 2015; 5(3): 500-503.

[5] Hechmi M, Khaled M, Abed S, El-Hassen A, Faiez R. Performance of olive cuttings (Olea europaea L.) of different cultivars growing in the agro-climatic conditions of Al-Jouf (Saudi Arabia). Am. J. Plant Physiol, 2013; 8(1): 41-49.

[6] Penso G A, Sachet M R, Maro L A C, Patto L S, Citadin I. Spread of 'Koroneiki' Olive by the cutting method at different times, AIB concentrations and the presence of leaves. Revista Ceres, 2016; 63(3): 355-360.

[7] Villa F, Silva D F, Dall'oglio P, Potrich C, Menegusso F J. Performance of substrates in rooting capacity of olive tree cuttings. Ver. Ciênc. Agrovet, 2017; 16(2): 95-101.

[8] Gai J, Gao W, Liu L, Chen Q, Feng G. Infectivity and community composition of arbuscular mycorrhizal fungi from different soil depths in intensively managed agricultural ecosystems. J. Soils Sed, 2015; 15(5): $1-12$.

[9] Kachkouch W, Touhami A O, Filali-Maltouf A, Modafar C, Moukhli A. Arbuscular mycorrhizal fungi species associated with rhizosphere of Olea europaea L. in Morocco. J. An. Plant Sci, 2012; 15(3): 2275-2287.

[10] Bompadre M J, Pérgola M, Fernández Bidondo L, Colombo RP, Silvani VA. Evaluation of arbus-cular mycorrhizal fungi capacity to alleviate abiotic stress of olive (Olea europaeaL.) plants at different transplant conditions. The Sci. World J, 2014; 1(1): 1-13.

[11] Silva F J, Ribeiro R C F, Xavier A A, Santos Neto J A, Souza M A. Rhizobacteria associated with organic materials in the control of root-knot nematode in tomato. Hort. Bras, 2016; 34(1): 59-65.

[12] Vejan P, Abdullah R, Khadiran T, Ismail S, Nasrulhaq Boyce A. Role of plant growth promoting rhizobacteria in agricultural sustainability. Molec, 2016; 21(5): 573.

[13] Masciarelli O, Urbani L, Reinoso H, Luna V. Alternative mechanism for the evaluation of indole-3-acetic acid (IAA) production by Azospirillum brasilense strains and its effects on the germination and growth of maize seedlings. J. Microb, 2013; 51(5): 590-597.

[14] Fukami J, Nogueira M A, Araujo R S, Hungria M. Accessing inoculation methods of maize and wheat with Azospirillum brasilense. AMB Express, 2016; 6(1): 3. doi: 10.1186/s13568-015-0171-y

[15] Li G, Bai X, Li H, Lu Z T, Zhou Y G, Wang Y K, et al. Nutrients removal and biomass production from anaerobic digested effluent by microalgae: A review. Int J Agric \& Biol Eng, 2019; 12(5): 8-13.

[16] Li G, Zhang J, Li H, Hu R C, Yao X L, Liu Y, et al. Towards high-quality biodiesel production from microalgae using original and anaerobically-digested livestock wastewater. Chemosphere, 2021; 273: 128578. doi: 10.1016/j.chemosphere.2020.128578.

[17] Alvarez C A, Stape J L, Sentelhas P C, Gonçalves J L M, Sparovek G. Koppen's climate classification map for Brazil. Meteorol. Zeitschrift, 2013; 22(6): 711-728

[18] Caviglione J H, Kiikl L R, Aramori P H, Oliveira D. Climate charts from
Paraná: IAPAR, 2000

[19] Oliveira M C, Vieira Neto J, Oliveira R S, Pio R, Oliveira N C. Rooting of cuttings of two olive cultivars submitted to the application of different fertilizers. Brag, 2010; 69(1): 99-103.

[20] Ferreira D F. SISVAR: A computer statistical analysis system. Ciênc. Agrotec, 2011; 35 (6): 1039-1042.

[21] Pio R, Costa F C, Curi P N, Moura P H M. Rooting of kiwi cultivars woody cuttings. Scientia Agraria, 2010; 11(3): 271-274.

[22] Vieira V C S, Melloni R, Vieira Neto J. Assessment of mycorrhizal interaction in olive tree (Olea europaea L.). Ver. Bras. Ciênc. Solo, 2011; 35(6): 1885-1892.

[23] Chatzistathis T, Orfanoudakis M, Alifragis D, Therios I. Colonization of Greek olive cultivars root system by arbuscular mycorrhizal fungus: Root morphology, growth, and mineral nutrition of olive plants. Scient. Agric, 2013; 70(1): 185-94.

[24] Ferreira G M R, Melloni R, Silva L F O, Martins F M, Gonçalves E D. Arbuscular mycorrhizal fungi in the development of olive tree seedlings (Olea europaea L.) Cultivated in southern Minas Gerais. Rev. Bras. Ciênc. Solo, 2015; 39(1): 361-366.

[25] Oliveira A F, Chalfun N N J, Alvarenga A A, Vieira Neto J, Pio R. Olive cuttings at different times, substrates and doses of IBA diluted in $\mathrm{NaOH}$ and alcohol. Ciênc. Agrotec, 2009; 33(1): 79-85.

[26] Rosa G G, Zanandrea I, Mayer N A, Bianchi V J. Propagation of Prunus spp. rootstocks by cutting: effects of genotype, branch developmental stage, and cutting type. Revista Ceres, 2017; 64(1): 90-97.

[27] Mohan J E, Cowden C C, Baas P, Dawadi A, Frankson P T. Mycorrhizal fungi mediation of terrestrial ecosystem responses to global change: mini-review. Fungal Ecol, 2014; 10(1): 3-19.

[28] Taiz L, Zeiger E, Moller I M, Murphy A. Physyology and plant development. 6. ed. Porto Alegre: Artmed, 2017; 858 p.

[29] Séry D J, Kouadio Z G, Voko B R, Zézé A. Selecting native arbuscular mycorrhizal fungi to promote cassava growth and increase yield under Field conditions. Front. Microbiol, 2016; 22(7): 2063-2074.

[30] Silva T F, Melloni R, Melloni E G P, Gonçalves E D. Non-symbiotic diazotrophic bacteria and the rooting of olive semi-hardwood cuttings (Olea europaea L.). Ciênc. Florest, 2017; 27(1): 67-71.

[31] Oliveira M C, Ramos J D, Pio R, Dos Santos V A, Silva F O R. Cutting rooting of promising olive cultivars for the Mantiqueira Range. Rev. Ceres, 2012; 59(1): 147-150.

[32] Hartmann H T, Kester D E, Davies J R F T, Geneve R L, Wilson S B Plant Propagation: Principles and Practices. Pearson, 9 Ed., 2017; 1024p.

[33] Vignolo G K, Picolotto L, Gonçalves M A, Pereira I S, Antunes L E C. Presence of leaves on rooting of blackberry. Ciênc. Rur, 2014; 44(3): 467-472.

[34] Lima R L S, Siqueira D L, Weber O B, Cazetta J O. Length of cuttings and part of the branch in the formation of saplings. Rev.Bras Frut, 2006; 28(1): 83-86.

[35] Picolotto L, Vignolo G K, Pereira I S, Goncalves M A, Antunes L E C. Rooting of blackberry cuttings in function of fertilization nitrogen in the mother plant. Rev. Ceres. 2015; 62(3): 294-300.

[36] Montero-Calasanz M C, Santamaría C, Albareda M, Daza A, Duan J Alternative rooting induction of semi-hardwood olive cuttings by several auxin-producing bacteria for organic agriculture systems. Span. J. Agric. Res, 2013; 11(1): 146-154.

[37] Quadros P D, Roesch L F W, Silva P R F, Vieira V M, Roehrs D D. Field agronomic performance of maize hybrids inoculated with Azospirillum Rev. Ceres, 2014; 61(2): 209-218. 